\title{
SOLDIERS AND POLITICS: THE POLITICAL RAMIFICATIONS OF THE WHITE UNION DEFENCE FORCES SOLDIERS' DEMOBILISATION EXPERIENCE AFTER THE SECOND WORLD WAR
}

\author{
François Oosthuizen \\ Department of History, Vista University
}

\begin{abstract}
The Second World War had a definite influence on the 1943 and 1948 general elections. Although the war had led to a victory for the United Party in 1943, warrelated issues led to the defeat of the same party five years later. After 1943, South Africa experienced numerous political, economic and social changes and within this context the demobilisation of the UDF soldier took place. As a result of these changes, the expectations some soldiers had for the post-war South Africa did not materialise. Few of the promises made to the soldier by the UP government were fulfilled. This led soldiers, experiencing difficulty in adapting to the postwar situation, to direct their anger towards the government. The aim of this paper is to determine firstly, the nature of the soldiers' problems and, secondly, whether their dissatisfaction found political expression.
\end{abstract}

The writer found that the problems experienced by some of the soldiers related to their economic status and their age. Furthermore, some also experienced problems with unemployment, shortages of housing and the high cost of living. These were, however, socio-economic problems which were also experienced by the public at large. It appears as if the UP did not address the real post-war problems, and they paid dearly for this mistake in the 1948 general election.

\section{INTRODUCTION}

When analyzing the political effects of the white UDF soldiers' demobilisation experience, it is important not to isolate the demobilisation process from the broader social, economic and political changes taking place within the Union. After the cessation of war, the Union was faced with the challenge of post-war reconstruction. This demanded the accommodation of both the social and economic consequences of industrialisation and the changes brought about by the introduction of a war economy. This made the return of ex-soldiers more complicated and po- litically problematic, as the problems of demobilisation often dovetailed with the socio-economic problems of the Union as a whole.'

From the start, the government had realised that demobilisation was a political issue. On announcing the demobilisation scheme in Parliament in 1944, Mr H.G. Lawrence, Minister of Welfare and Demobilisation, had stated : "If I evaluate public opinion correctly, most people feel that the way in which the Government will tackle the problem of reinstating the soldiers in civilian life, will determine the support they get from the public". The manner in which the government tackled the task of demobilisation was thus considered to be the "acid test" which would determine the support it would receive from the public. ${ }^{3}$

When ascertaining the extent of the success the government had in retaining the public support, one inevitably touches on the reaction to and relationships between various groups more specifically those relating to the soldier, the State and the ordinary civilian - and how they were affected by demobilisation.

K.J. Gibbs : Demobilisation after World War II; The process and politics of reinstating Union Defence Force volunteers into civilian life, 1943-1948 (unpublished Honours paper, UNISA 1990), p.11.

Directorate Documentation Service, Pretoria, Pamphlet Collection, Box 185, pamphlet number 3489 , Appendix to Springbok, December 1944

Debates of the House of Assembly, vol.49, 1944, col.6048, 
The following issues will be considered in this paper : Did the soldiers have any reason to feel discontented? Did the soldiers' dissatisfaction find political expression? How did demobilisation influence the relations between the soldier, the State and the ordinary civilian?

\section{FEELINGS OF DISCONTENT}

The question as to whether the ex-soldier had reason to feel discontent towards the demobilisation process, was dependant upon numerous factors. Firstly, the demobilisation machinery was not neutral in its treatment of ex-soldiers. This is reflected in the differing scales of benefits which were largely politically motivated and reflected a wider social and political reality. In a report in The Forum, the discrimination in the scale of gratuities paid to ex-soldiers is attributed to the so-called "South African pigmentocracy" who did not recognise that equal sacrifices afforded equal pay. Values extracted by the Cape Standard from an analysis of gratuities paid to ex-soldiers explained the discriminatory scale of benefits in the following manner : "A European woman is worth half a European man. A Coloured man is worth one third of an European man. An African man is worth half a Coloured man". ${ }^{4}$

The Springbok Legion's major complaint concerning the demobilisation scheme was related to these greater political discriminatory processes facing the Union, and was directed primarily towards the "shoddy treatment" given to the black soldier : "The people most in need of help, received the least". ${ }^{5}$ Although one can expect that those who received the least would be the ones most likely to be dissatisfied; it was those who received the least who also had the least political means of redressing their grievances. This resulted from job reservation, the pass laws, the exclusion from owning property and other limits placed on the black population.

The white soldier, on the other hand, had greater political status and therefore their attitudes towards the demobilisation machinery had greater significance in the parliamentary political structure. ${ }^{6}$ Within the white group, the responses were varied and dependant upon a variety of factors - such as the economic status and age of the soldier and the soldier's ability to bring about his successful reinstatement into civilian life. In terms of economic status, exsoldiers in the middle-to-upper income groups generally had less reason to complain than those in the lower income groups. They had the benefit of education and the financial support of their families to see them through their time of reinstatement into civilian life. Those in the lower income groups suffered as a result of delayed repatriation and discharge, and more specifically from rejection and delay in the processing of their applications for financial assistance. The dependence of these soldiers on the benefits and assistance given by the demobilisation scheme, made a successful reinstatement into civilian life crucial. However, it also made reinstatement more problematic.

Army life afforded the soldiers in the lower income group a system of social security which did not exist in civilian life. If he was ill, his ordinary pay continued, and he got free medical care. Where most business in civilian life is done through the medium of money, in the army it is done by means of rations and allocations, without using any money at all? It seemed that many of the ex-soldiers in the lower income groups became used to the benefits of army life and on leaving army life experienced a drop in their standard of living. Therefore, discontent was most likely to be acute amongst these individuals and there was the possibility of the discontent finding expression in the political sphere.

Age also played an important role in the soldiers' responses to demobilisation and here one has to distinguish between the younger and the older soldier. Soldiers experienced a tremendous camaraderie and a common sense of purpose during the war, something not found in civilian life. Once demobilised the soldier, and more particularly the younger soldier who joined the Service straight from school, felt lonely and depressed. In contrast to the older soldier who was employed prior to the War, the younger soldier did not experience the same sense of belonging to a place of work or community. They experienced the post-war world as a cold, hard place where everyone was out for himself. Even their closest friendships formed during the war, did not last. ${ }^{8}$

The Forum 7(7) 13 May 1944, p. 15.

Ibid. (Also compare L.W.F. Grundlingh: "Soldiers and Politics; A study of the political consciousness of Black South African soldiers during and after the Second World War". Historia 36(2), 1990.)

6 T.Karis and G.M.Cater (eds) : From Protest to Challenge: A Documentary History of African Politics in S.A. 1882-1964. II (Hoover Institution Press, Stanford University, 1973), pp.69 and 73.

South African National Museum of Military History, File B.34(68), "When we all got home", Booklet No.6, Army Education Service, p.2.

8 Ibid. 
Post-war employment also contributed to feelings of discontent and even disillusionment, amongst demobilised soldiers. The general economic situation in the Union, of course, played the most important role in the provision of post-war employment. The Depression of the Thirties was not forgotten, and many soldiers feared a repetition of the Depression years. Despite these fears, the government nonetheless committed itself to ensuring 'suitable employment' to all of the returning soldiers. 'Suitable employment' was considered to be employment under conditions no less favourable than those existing at the time of the soldier leaving his employment in order to enlist.? any position which became vacant during the war. The same occurred in Pretoria and Bloemfontein. This happened, despite requests to State Departments to fill vacancies only temporarily. The Springbok Legion described the political nature of the event as "a living example of what the promises of the anti-war opposition amount to"."1

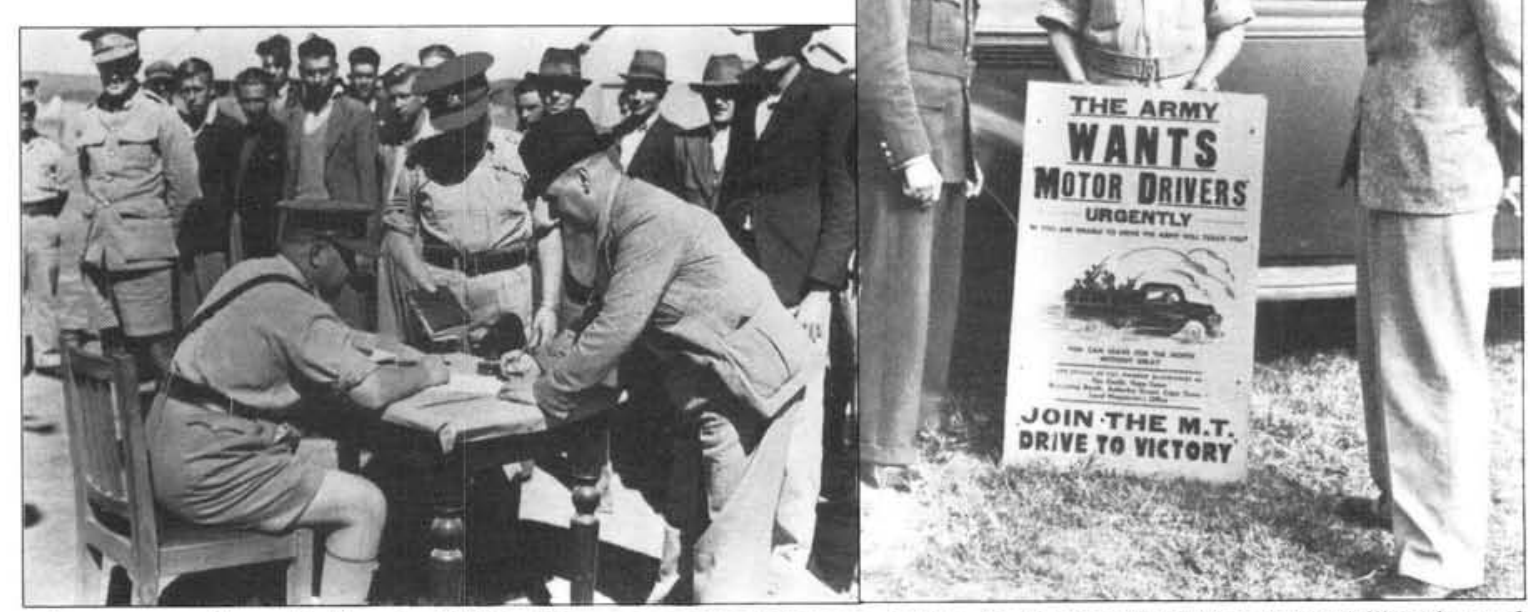

Army recruits enlisting in 1939. The government soon came to realise that the demobilisation of these men would be far more problematic than their mobilisation. (SADF Archives)

The government, however, quickly realised that demobilisation was an even greater problem than mobilisation had been at the beginning of the war. Some of the ex-soldiers experienced delays in finding employment. There were those ex-soldiers who were unemployed prior to the War and this caused problems. Generally speaking, army experience did not improve their prospects of employment and some of them had little incentive to find employment. Many servicemen lived at the expense of the Defence Department, the result of a provision made in the demobilisation plan that soldiers not finding employment be retained on military strength. ${ }^{10}$

Some ex-servicemen even experienced problems in returning to their pre-war employment. The Nationalist Brakpan Town Council, for instance, adopted a policy debarring all men and women serving in the Forces from applying for
According to K.J. Gibbs the most important reason why ex-soldiers experienced problems in finding post-war employment, related to the fact that the economy was not ready to receive them. Post-war difficulties in acquiring new machinery and raw materials stunted industrial expansion which was necessary to provide employment opportunities. ${ }^{12}$ In this regard the Union differed significantly from the demobilisation approach adopted by the United Kingdom. In the United Kingdom the post-war reconstruction did not emphasize demobilisation as such, but rather the re-allocation of manpower. By coordinating the discharge of soldiers with the conversion of industries from war to peace-time production, demobilised soldiers were ensured of employment. ${ }^{13}$

Once the soldier was finally settled in a job and had received financial assistance, the next problem facing the ex-soldier was finding ac-

\footnotetext{
Union War Histories (UWH Civil), Box 94. A brief progress report by the Intelligence and Information Section, 1 Aug 1945, p.4.

10 K.J. Gibbs : Demobilisation after World War II, p. 31.

Pamphlet of the Springbok Legion entitled: "Victimisation of Volunteers, Brakpan Town Council", date unknown.

12 K.J. Gibbs: Demobilisation after World War II, p. 31.

Archive of the Adjutant General, Box 28, file AG(3)404/1 Demobilisation in Britain, 1 May 1947, p.2.
} 
commodation and trying to keep up with the cost of living. This gave the Nationalist Party opposition the opportunity to embark on what The Forum called "Phase No.2" of their bid for power. They devoted a great deal of attention to blaming the United Party for the difficulties being experienced. ${ }^{14}$ It was said that the food shortages experienced in the Union were more valuable to the Nationalists as political ammunition than even housing. ${ }^{15}$ The Volksblad held the opinion that the government's lack of foresight was the direct cause of the food shortages, as "convoys had devoured a lot of the Union's food, thanks to the war policy".16 The soldiers' discontent was understandable, particularly when these conditions dragged on for years after the ending of the war.

The shortage of housing became a crucial political issue, not only to the ex-soldier but to the general public as well. According to a report of the Social and Economic Planning Council tabled in 1944 , it was reported that within the first ten years after the war 150000 houses had to be built to meet the demands of the European population. The Council also pointed out that quite apart from the shortage of houses for blacks which it estimated at 125000 , a further 140000 houses had to

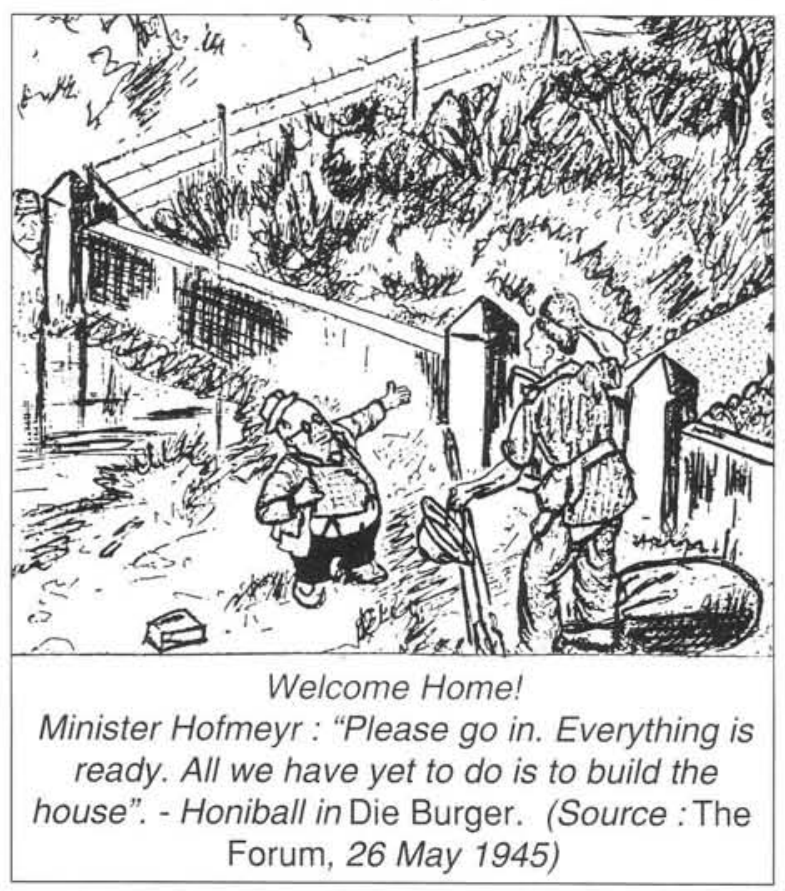
be built for blacks within the following 11 years. ${ }^{17}$

Despite legislative measures - such as the Housing (Emergency) Powers Bill - designed to speed up the building of houses on a national scale, an official document reviewing official progress made up to 1947 , still remarked on the State's "inadequate contribution". ${ }^{18}$ Reports from all centres of the Union gave gloomier and gloomier tidings for the homeless: "You are almost asking for the impossible. Accommoda- tion in Cape Town is at a premium" and "We regret to inform you that there are no houses or flats available in Durban". ${ }^{9}$

By 1948 the housing situation had improved only for some. Although ex-soldiers were given preference in finding accommodation at low rates, many of them could still not afford to buy their own house. Furthermore, at a time when ex-soldiers found it difficult to obtain suitable accommodation, the government proposed an immigration scheme. The immigration scheme was an attempt by the UP government to overcome the skilled manpower shortage in the Union. ${ }^{20}$ The soldiers had to compete with over 60000 immigrants in the struggle for both employment and accommodation. Some viewed this step as an example of the government's blatant ignorance of the ex-soldiers' post-war needs.

The frustration felt by some ex-soldiers when accommodation could not be found was sometimes directed at the government. Realising the political significance of the ex-soldiers' dissatisfaction, the government unexpectedly issued permits for the building of 1228 flats for ex-soldiers in late April 1948. ${ }^{21}$ One might well ask why the government was trying to rescue the situation at such a late stage. But, if one takes into account that this step was taken a month before the 1948 election, it was obviously a political ploy to win the support of the ex-soldier.

Other issues of political importance were the high cost of living and the shortages of food and other commodities which were still evident by 1948 . For many these "bread and butter" issues caused resentment and discontent, particularly when the UP politicians claimed that

\footnotetext{
The Forum 7(24) 9 Sep 1944, p. 15

The Forum 7(45) 3 Feb 1945, p. 15

lbid.

UWH Civil, Box 46. White Paper "Post-war reconstruction of the Union", p. 11

18 R. Bloch and P. Wilkinson: "Urban control and Popular struggle: A survey of State Urban Policy 1920-1970", African Perspective 20, 1982, pp.21-22.

19 The Forum 8(14) 7 Jul 1945, p. 17

20 K.J. Gibbs : Demobilisation after World War II. p.47. (Also compare M. Lipton : Capitalism and Apartheid (Aldershot 1985), p.274 and T.R.H. Davenport: South Africa: A Modern History (London 1991), p.320.)

21 K.J. Gibbs: Demobilisation after World War II, p.47.
} 
the voters were content and that the Union and its people had never been better off. The cost of living for the lower income groups had risen by an alarming $41 \%$ since 1938 , and for those in the higher income groups even more.22 The rising cost of living is clearly illustrated by the retail prices which climbed from 100.0 in 1938 to 151.8 in 1947.23 It was difficult for the exsoldier, who had to establish or re-establish a home after the war, and still found themselves no better off than when they were demobilised. Even the financial assistance offered did not help them in the long term, as many found themselves in financial difficulty and were unable to pay their debts.

\section{POLITICAL EXPRESSION}

Thus, during the war, the UP had no economic successes to pride themselves on. In fact, few of the promises made to their supporters concerning food shortages, housing, employment and demobilisation benefits to the ex-soldier were fulfilled. There was the possibility that the government's inability to fulfil its promises, might have political repercussions. When considering the political effect of the soldiers' demobilisation experience, certain aspects have to be borne in mind.

Many of the soldiers who enlisted, joined the UDF straight from school. Consequently, many of the soldiers could have been politically naive and might have joined up mainly for the adventure. This view is supported by J. CrwysWilliams in A Country at War, 1939-1945; The Mood of a Nation. She interviewed more than 80 ex-soldiers who stated that it was primarily adventure that motivated them to enlist and that political awareness only came later. ${ }^{24}$

\section{F.D. Tothill supports this view : "Although} South Africa's forces consisted of volunteers, that did not necessarily mean that people 'joined up' because they were in favour of the war". ${ }^{25}$ Tothill suggests that the economic conditions prior to the war, contributed to the fact that some men and women "irrespective of political leanings, saw military service as a way out of their economic difficulties" ${ }^{26}$ Thus, political conviction was not the only driving force for enlistment.

Demobilisation was, furthermore, a personal matter. The soldier was mainly preoccupied with what was going to happen to him and was concerned about larger social, economical and political matters only in so far as they had an influence on his reinstatement to civilian life : "When the repatriation was over and they had been through the demobilisation mill, the soldiers' major concern was to forget about the army and the war and to blend into civilian life". ${ }^{27}$ Once the war was over, the strong civilian orientation prevalent amongst the soldiers made them reluctant to become politically involved. They did not want to support the Springbok Legion's call for overt political action. ${ }^{28}$ This seems to suggest that the war itself did not have a politicising effect on the majority of the troops..$^{29}$ This attitude might help to explain why feelings of solidarity never developed amongst ex-soldiers. Once they were out of uniform their different educational, social and economic backgrounds became more apparent. The chances of a soldiers' party forming were very slim; and it was clear that common wartime experience by no means resulted in common political philosophy. ${ }^{30}$

The question also arises whether the soldiers were ever perceived to be a political force by the different political parties. The UP government took cognisance of the dissatisfaction amongst ex-soldiers, and concentrated a great deal of its 1948 election campaign on convincing the ex-soldier that demobilisation had been successful. Newspaper editorials were interspersed with political rhetoric trying to persuade the soldiers and general public that the "promises had been carried out' and that there were 'no forgotten men'. ${ }^{31}$ Even Lieutenant General G.E. Brink, Director General of Demobilisation, highlighted the successes of the Directorate and stated the following: "Ek beweer dat SuidAfrika se demobilisasieplan besonder gunstig vergelyk met die van ander lande. Dit is ' $n$ plan wat ingegee is deur moed en visie, deur

2 Ibid. p.48.

Bureau of Census and Statistics, Fifty Years of Union Statistics, p.G-16.

J. Crwys-Williams: A Country at War: The Mood of a Nation, 1939-1945 (Rivonia 1992), p.34

F.D. Tothill : "The soldiers' vote and its effect on the outcome of the South African General Election of 1943". Southern African Historical Journal 21, 1989, p.91.

Ibid.

S.A. Stouffer : The American Soldier, II (New York 1949), p.552.

K.J. Gibbs : Demobilisation after World War II, p.50.

Ibid.

30. Ibid. (Also compare L.W.F. Grundlingh: "Soldiers and Politics: A Study of the political consciousness of Black South African soldiers during and after the second World War". Historia 36(2), 1991.)

Sundar Times, 2 Jan 1949 
simpatie en aanmoediging vir die oud-vrywilliger en deur die vasberadenheid van die land se leiers dat niemand hierdie keer vergeet sal word nie". 32

The UP felt that the soldiers owed it to them to vote the government back into power : "It is traditionally a soldier's privilege to grumble, but equally it is traditional to know where his duty lies". ${ }^{33}$ This view explains the contentment experienced by Smuts and his party. They were not concerned that the problems experienced by the ex-soldier or the ordinary civilian could turn the support against them. Broodryk quotes the Natal Daily News which stated that Smuts and his supporters were not worried about winning the 1948 general election, but were more concerned about the extent of their victory. ${ }^{34}$

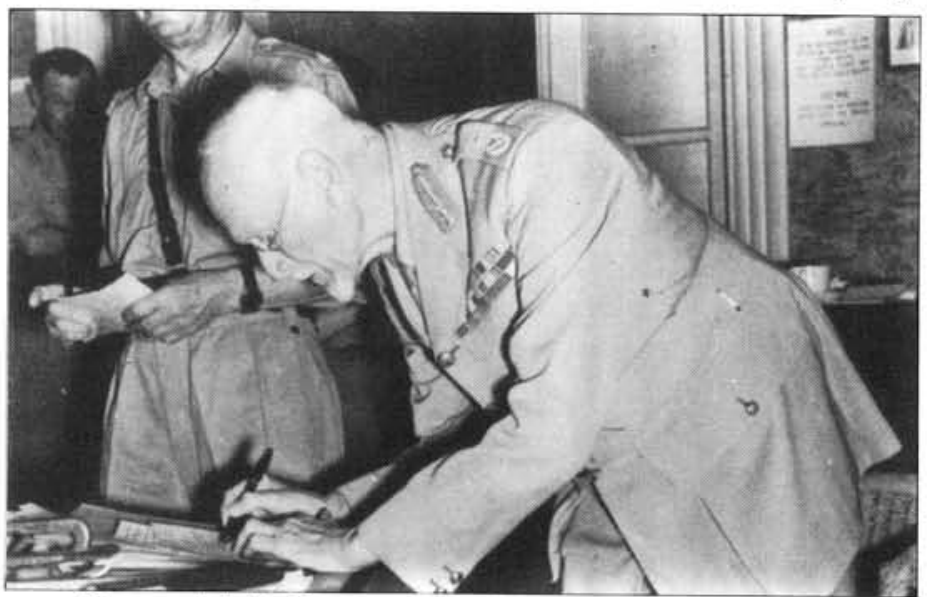

General J.C. Smuts casts his vote in Egypt, 1943. (SADF Archives) soldiers which separated them from the civilian voters. Factors such as 'voting parades' held under military discipline and the rumours that the ballot was not secret contributed to the illusion that the UP's position was by no means as solid as it appeared. He goes on and states that : "If the artificial nature of the 1943 election is acceptable, then the UP's defeat in 1948 is easier to grasp". ${ }^{37}$

On the other hand, the soldiers' vote was in accord with the majority of South Africans.

While soldiers had a greater stake in the war and might be more concerned to retain a government which would be sympathetic to their cause, their support of Smuts reflected the prevailing optimism at home of a successful outcome of the war. ${ }^{38}$ Broodryk also emphasizes that the Allied forces' fa-

Did the soldiers feel compelled to vote for the UP? What about the soldiers' grievances? Could that not have persuaded them to vote otherwise?

In order to provide answers to the above mentioned questions one could start by analyzing the United Party's 1943 election victory. The UP received much greater support amongst the soldiers (almost $95 \%$ of the soldiers' vote) than from the rest of the country. ${ }^{35}$ This could indicate influencing of the soldiers, but could also be a reflection on how the soldiers felt. Thus, on the one hand, Tothill states that the 1943 election result was an "illusion of triumph" and that the result contributed to a misleading interpretation of the UP's strength. ${ }^{36}$ The artificial nature of the UP victory could mainly be attributed to the special arrangements made for the vourable situation by 1943 , played an important role in the outcome of the election. Smuts realised that it was unlikely that the voters would reject the UP amidst the war, especially at a time when the Allied forces were gaining the upper hand. ${ }^{39}$

Tothill placed considerable emphasis on the important role of the soldiers' vote in the outcome of the 1943 election, but ignored the differences between conditions prevailing during the war and the unique character of the post-war world. According to Gibbs, a far more likely explanation is that the UP was at its peak in 1943 and thus reflected the interests of the majority, rather than the soldiers' vote giving an artificial indication of the UP's support. ${ }^{40}$

Therefore, it would be wrong to ascribe the

\footnotetext{
$32 A G(3)$, Box 179, file $A G(3) 404 / 2$ vol III Verklaring deur Lt Genl G.E. Brink oor die steun wat die Direksie van Demobilisasie en ander Staatsdepartemente aan Oud-Vrywilligers verleen het, 25 Mar 1948.

3 K.J. Gibbs : Demobilisation after World War II, p.53 and The Star 10 May 1948.

34 M. Broodryk: "Die invloed van die Tweede Wêreldoorlog op Suid-Afrikaanse Algemene Verkiesings", S.A. Historical Society Conference, January 1993, p.234.

35 Ibid., p.241.

36 F.D. Tothill : "The soldiers' vote and its effect on the 1943 general election", p.93.

37 Ibid.

38 South African National War Museum. File B.34(68), Army Education Service. Booklet No 6: "When we all got home", p.8.

39 M. Broodryk: "Die invloed van die Tweede Wêreldoorlog op Suid-Afrikaanse Algemene Verkiesings", pp.234-235.

${ }^{40}$ K.J. Gibbs: Demobilisation after World War II, p.56.
} 
election results only to war-related factors. Similarly, the decline in the UP support after the war, must be looked at in terms of the altered post-war political climate rather than the soldiers' political preferences ${ }^{41}$ T.R.H. Davenport is of the opinion that the UP could well have tory factors are discussed namely, the change in the economic interests of the UP which had become too costly for white agriculture and labour, the disarray in which the UP found itself
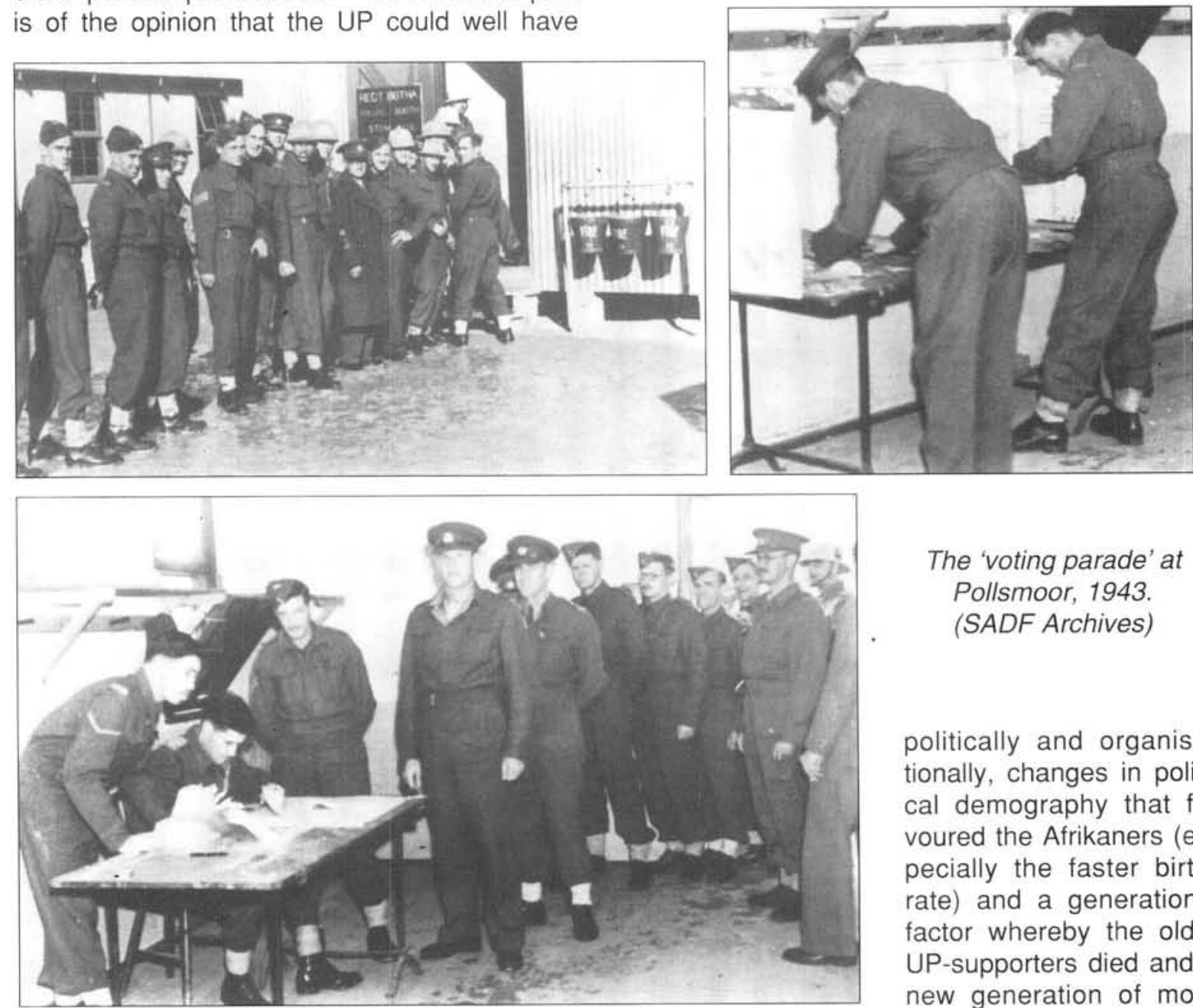

The 'voting parade' at Pollsmoor, 1943.

(SADF Archives)

drawn credit from having brought South Africa out of the war on the winning side. But, they seemed to have overcapitalised on this achievement as well as on two other events, namely the Royal visit to the Union and the immigration scheme : "too much was made of these achievements as vote-catching factors" ${ }^{\prime 2}$ In addition to these factors, Davenport mentions other political "pin-pricks" in the fall of the government, such as the restlessness of the ex-soldier who did not adjust successfully and the slow progress made in the government's housing programme. ${ }^{43}$

Adding to the discussion on the changed postwar political climate, Merle Lipton emphasizes the changes that had taken place from the early 1940 s to the late 1940s, as an explanation for the fall of the UP government. Four contribu- militant Afrikaners played an important role.44 All of this seems to support the assumption that too much emphasis was placed on the dissatisfaction about demobilisation amongst ex-soldiers and the political consequences thereof in the fall of the UP. Other issues seemed to become more important in influencing the exsoldiers' vote.

One cannot therefore infer that the soldiers who returned necessarily voted 'Herenigde Nasionale Party' (HNP) because the soldiers returned from the war with a greater sense of "South Africanism". Many did not forget the anti-war factions during the war that threatened the interests of the soldiers, most soldiers seemed to be absorbed into civilian life fairly easily, and while soldiers might not have been supporters of the UP policies, most still supported Smuts -

41 lbid. p.55.

42 T.R.H. Davenport: South Africa; A Modern History, p.307

43 Ibid,

44 M. Lipton : Capitalism and Apartheid, p.278. 


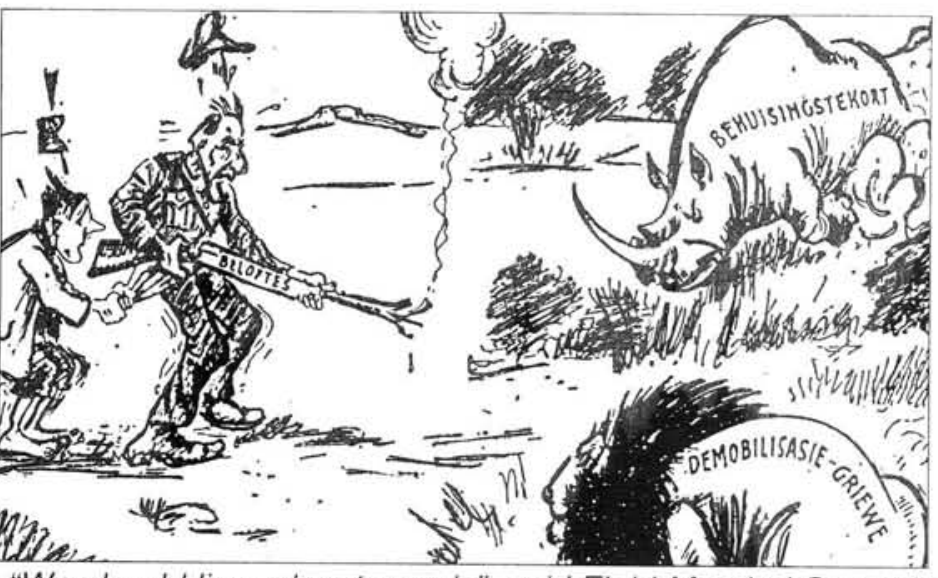

"We should live adventurously", said Field-Marshal Smuts in Canada recently, little knowing what adventures await him in South Africa in connection with the housing shortage and demobilisation grievances. - Honiball inDie Burger. (Source: The Forum, 21 Jul 1945)

and therefore voted UP - if only as a vague symbol of an ideal once considered worth fighting for. ${ }^{45}$

In all, it thus seems that the soldiers' interests were economically determined, rather than being influenced merely by their participation in war.

\section{RELATIONS WITH THE STATE AND THE GENERAL PUBLIC}

In the introduction, it was stated that the war also touched on the relations between different groups of people. So far this paper has touched on the soldier and his expectations of the government, and the government and its expectations of the soldier. But, how did the demobilisation process influence those individuals who did not enlist, and those who sympathised with the war effort but did not join up because their skills were needed within the Union, such as the keymen?

When viewing the dissatisfaction of the ex-soldier against the broader context of post-war social and economic reconstruction, one notices that the feelings of dissatisfaction were by no means confined to the ex-soldier. Everyone was touched by the war, whether by losing a loved one or suffering the want of luxuries. ${ }^{46}$
The non-volunteers had reason to feel discontent as well, especially the keymen who were sometimes overlooked for promotion in an effort to compensate soldiers for their absence. ${ }^{47} \mathrm{Re}$ sentment was felt by temporary workers who were displaced by the return of exsoldiers. There were also cases of civilians who felt that soldiers were placed in positions for which they were not qualified. Sometimes the soldier changed his pre-war employment and then had to rely on civilians to teach him or her the new job. ${ }^{48}$ Although some non-volunteers felt unhappy about this, there were others who saw their assisting the exsoldier to adapt to his new job as their contribution towards the war effort. Although attempts were made to find employment for workers displaced due to the return of ex-soldiers, the government did not feel the same sense of obligation towards them as they did towards the soldier. ${ }^{49}$ This in itself could have led to criticism of the government and could have had political implications.

\section{CONCLUSION}

It thus seems that the government had expected demobilisation to be the most stringent test of its ability to retain public support. It went to great lengths to ensure that the soldiers' return to the Union was smooth. As it turned out, this became increasingly difficult, since other issues became more important. The government had clearly misread the situation and lacked clearness of vision in regard to the postwar problems the country had to face. The UP paid for this mistake in the 1948 election, which was to a large extent still fought on war-related issues.

The government did not grasp the importance and influence of broader social, economic and political changes taking place in the reconstruction of the post-war South Africa. The government too did not pay enough attention to the changing relations between different groups of people directly or indirectly involved in the demobilisation process.

45 K.J. Gibbs: Demobilisation after Worid War II, p.56.

46 J. Crwys-Williams: A Country at War, p.144.

47 Personal interview: Mr J, van Dyk, Krugersdorp. 25 Aug 1992.

48 Personal interview : Dr C.M. Bakkes, Pretoria, 18 Aug 1992.

49 The Civil Re-employment Board, one of the organisations that assisted in the demobilisation of soldiers prior to the establishment of the Directorate of Demobilisation, stated that one of their functions was to secure employment for any person displaced because of the re-absorption of ex-soldiers. No such undertaking was, however, made by the Directorate when it took over the duties of the Board. (Archive of the Secretary for Defence, Box 3581, Civil Re-employment Board Budget Speech, 1942.) 